\title{
THE EFFECT OF FOREIGN REAL ESTATE INVESTMENTS ON HOUSE PRICES: EVIDENCE FROM EMERGING ECONOMIES
}

\author{
Hassan Fereidouni GHOLIPOUR \\ Center of Real Estate Studies (CRES), Universiti Teknologi Malaysia (UTM), Skudai, 81310 \\ Johor, Malaysia \\ E-mail: hassanhgf@gmail.com
}

Received 28 January 2012; accepted 26 April 2012

\begin{abstract}
In recent years, most emerging economies have experienced large foreign real estate investment (FREI) and an appreciation of house prices. The purpose of this study is to empirically investigate the effects of FREI on house prices by employing a panel VAR model. Using data from 21 emerging economies over the period 2000-2008, our empirical results show that FREI contributes to house price increases. Moreover, the results indicate that the dominant source of house price fluctuations in emerging economies come from the housing market itself.
\end{abstract}

KEYWORDS: House prices; Foreign real estate investments; Capital inflows; Emerging economies; Panel VAR

REFERENCE to this paper should be made as follows: Gholipour, H. F. (2013) The effect of foreign real estate investments on house prices: evidence from emerging economies, International Journal of Strategic Property Management, 17(1), pp. 32-43.

\section{INTRODUCTION}

Capital flows from abroad (such as foreign direct investment (FDI), portfolio investment, cross-border loans to domestic branches of foreign banks, foreign debt) have been recognized as one the main components of the boom-bust cycle which often resulting in economic crisis in most emerging economies (e.g. South East Asia in the mid 1990s, Mexico in the early 1990s, Argentina in the 1990s). It is argued that "a general boom-bust cycle begins with a boom stage of credit expansion, investment increases, asset prices rise, and increasing capital inflows, and ends up with a bust stage when all those gains reverse" (Kim and Yang, 2011, p. 293).
One of the main categories of capital inflows in most emerging economies is foreign direct investment (FDI). In particular, FDI in real estate sector (FREI) has grown considerably in most of these countries in recent years. For example, FDI inflows into China's real estate market accounted for $10-15 \%$ of total FDI from the middle of 1990 s to 2009 (He et al., 2009). In 2007, real estate ranked second only to India's computer software industry in attracting FDI (Economist Intelligence Unit, 2008). More evidences on the recent surges of FREI in emerging economies can be seen in Appendix A.

Similarly, during 2000-2008, house prices rose rapidly across much of the emerging economies. Figure 1, based on Global Market Infor-

Copyright (C) 2013 Vilnius Gediminas Technical University (VGTU) Press Technika 
mation data, shows real house price trends in some emerging economies. The Figure 1 shows that house prices rose in real terms in most of these countries. For example, over the 9 years from 2000 to 2008 , real house prices rose $75 \%$ in Mexico, $78 \%$ in Hungary, 26\% in China, $40 \%$ in Poland and $45 \%$ in Tunisia.

Based on the above statistics, it can be observed that increases in FREI have gone with continues rise in house prices in recipient countries. This led economists and observers to suggest that real estate price appreciations in some emerging economies have been stimulated by the increased amount of FREI (e.g. Cordero and Paus, 2008; Mihaljek, 2005; BenYehoshua, 2008). For example, Mihaljek (2005) argues that the opening of Croatia's real estate market to European Union residents could increase house prices. However, on the other hand, some argue that FREI is not a cause of high house prices in emerging economies because FREI is a tiny portion of the total real estate investment (e.g. Chan, 2007).

To shed some light on above issue, the present study focuses on the relationship between
FREI and house prices. There are some ways that capital inflows (including FREI) may result in increased real estate prices: (1) direct demand for assets, (2) liquidity and (3) economic booms. First, the increased level of foreign capital into the real estate market would raise the demand for property. Since in the short run the supply of real estate is relatively fixed, this would tend to drive real estate prices up (Mihaljek, 2005; Kim and Yang, 2009). The second channel is a liquidity channel that may allow capital inflows to result in an increased money supply and liquidity which in turn boost asset prices (Kim and Yang, 2009). Regarding the third channel, capital inflows tend to create economic booms in a country, which then leads to an increase in asset prices (World Bank, 2001; Kim and Yang, 2009).

While there have been a series of published papers on the effects of capital flows (e.g. aggregate capital inflow, FDI, portfolio investment, hot money ${ }^{1}$ ) on asset prices, such as Brixiova et al. (2010), Kim and Yang (2009), Bo and Bo (2007), Zheng et al. (2009), Guo and Huang (2010), to our knowledge, no empirical

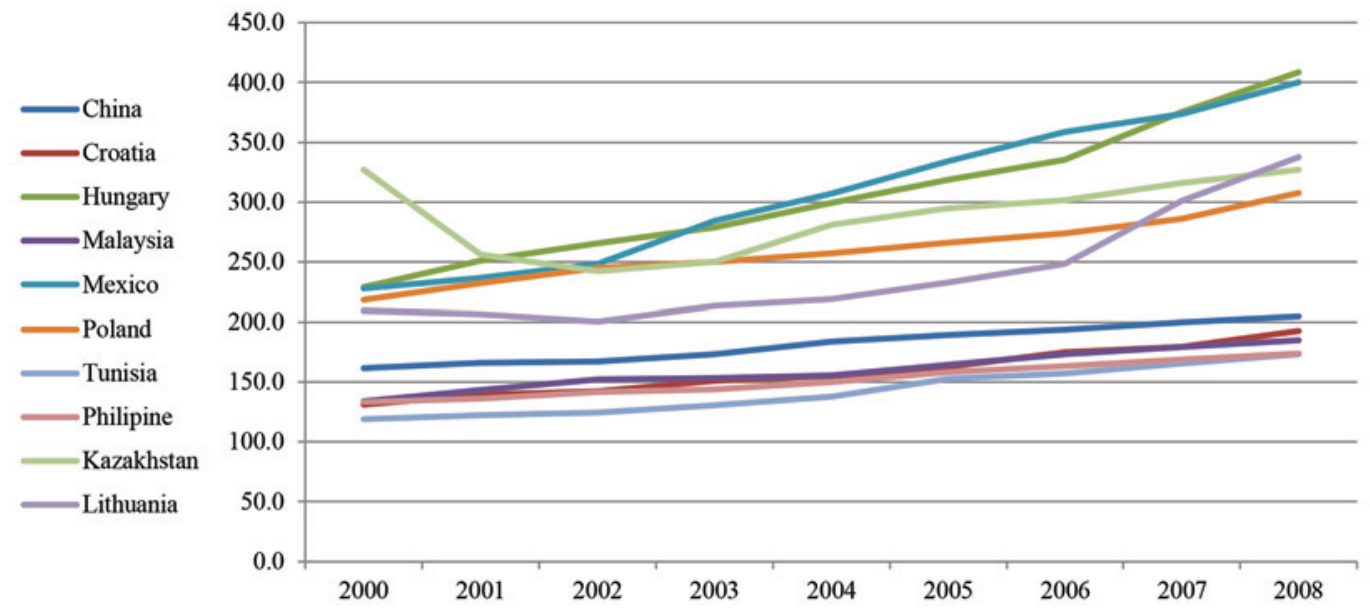

Figure 1. Real house price increases in selected emerging economies: 2000-2008 Source: Global Market Information Databases

1 "Hot money" refers to the flow of speculative funds (or capital) from one country to another in order to mainly earn a short-term profit on interest rate differences and/or anticipated exchange rate shifts (Chari and Kehoe, 2003). 
study has focused on FREI' effects on house prices across a large number of countries. In fact, owing to the lack of data on FREI no specific empirical study has been performed. There is a reason why it is important to complement studies of aggregate FDI and property prices, with analyses of FREI. Studying FREI rather than aggregate FDI helps policymakers to understand which type of FDI contributes to real estate price hikes in emerging economies. For example, FDI in other sectors (such as FDI in chemical products, beverages and tobacco, hunting and fishing, publishing and printing) do not have the same economic impacts as FREI does on the property markets. To address this gap, the present paper empirically investigates the effects of FREI on house prices using data from 21 emerging economies over the period 2000-2008. By employing a panel VAR approach, our results indicate that FREI contributes to house price appreciations in the emerging economies. However, FREI only plays minor role in house price appreciations.

The rest of this paper is presented as follows. Section 2 reviews some of the relevant studies on capital inflows and asset prices. In section 3, we identify the factors that will be relevant for our econometric investigation, drawing from the empirical and theoretical literature. Section 4 explains the methodology and describes the data. Section 5 presents the results. Finally, Section 6 concludes this paper and provides some implications for policymakers in the emerging economies.

\section{LITERATURE REVIEW}

There have been a number of studies that provide appealing insights on capital inflows and asset price appreciations. This section of paper intends to review some of the articles which are more relevant to our study.

Bo and Bo (2007) used an error correction model and granger causality test to examine the relationship between house prices and international capital flows over the period of 1998 to 2006 in China and concluded that in the short run, the increase of housing prices attracts the inflows of foreign capitals; in the long run, foreign capitals help to boost the rise of house prices. Kim and Yang (2011) empirically examined the effects of capital inflows on asset prices (including stock, land and nominal and real exchange rate) among emerging Asian economies (South Korea, Indonesia, Malaysia, Philippines, and Thailand). Their empirical results suggested that capital inflows contributed to asset price appreciations in emerging Asian economies. Brixiova et al. (2010) concluded that massive capital inflows led to credit and real estate booms during 2000-2007 in Estonia because these external financing fuelled rapid domestic credit growth, mainly to households for real estate purchases in the form of foreign currency loans. Kim and Yang (2009) empirically investigated whether capital flow induced domestic asset price appreciations in the case of Korea. They found that capital inflow shocks have caused stock prices to increase. Moreover, their results suggested that the influence of capital inflow shocks is limited in other part of economy (land prices, nominal and real exchange rate and liquidity). Calvo et al. (1996) argued that rising capital inflows would be associated with higher equity and real estate prices in most of the capital-importing countries. Likewise, Guerra de Luna (1997) noted that episodes of large capital inflows have often been associated with growing imbalances, such as an increase in real estate prices and a real currency appreciation. Downs (2007) also concluded that a surge in capital flows was a crucial factor influencing the rise in global commercial real estate prices during the 2002 to 2007 period. Copeland (1991) pointed out that foreign capital inflow increases land and housing costs, making local businesses (especially small and medium-sized enterprises that often do not own real property) very difficult to 
run in a profitable way because of high rental costs. In his study on stock price bubbles for the case of Malaysia and Singapore, Rangel (2010) found that the real GDP growth and capital flows were consistently significant explanatory variables. Using times series data for 1990 through 1992, Redman and Gullett (1998) examined the impact of foreign investor purchases and sales of commercial properties on property prices in the United States. By applying multiple regressions, they found that the existence of foreign investors would increase demand adequately to raise property prices.

Guo and Huang (2010) studied the extent of the impact from hot money (speculative capital inflow) on the fluctuations of China's real estate market and stock market. Their results indicated that hot money has driven up property prices as well as contributed to the accelerating volatilities in both markets due to its enormous size and its short-term characteristic of investing. By applying a panel data model, Cheng et al. (2006) found that the hot money had significantly contribution to the price change of real estate in China.

Jansen (2003) examined the effects of private financial capital inflows in Thailand in the pre-crisis period. He found that private capital inflows is associated with higher asset prices, lower lending rates, surges in bank lending and domestic spending driven by higher investment, higher output, modest inflation, and modest real exchange rate appreciation. Zheng et al. (2009) showed that home prices in Chinese cities increases in response to FDI inflows. Ben-Yehoshua (2008) argued that strong economic growth and impressive flows of FDI contributed to real estate price increases in metro cities of China. In another study, Cordero and Paus (2008) noted that large amount of foreign investment in Costa Rica' real estate sector (about $25 \%$ of total FDI inflows) contributed to development of real estate prices over the period of 2004-2006. Sajor (2003) argued that unprecedented flow of international portfolio investment in real estate facilitate boom and bust property cycles during the 1980s and 1990s globally. A study by Rajan and Siregar (2002) showed that portfolio capital inflows in East Asia was the main factor that explain the rebound in regional growth rates, surges in equity prices and stabilization of exchange rates during the pre-crisis boom period (between 1990 and 1996). Mihaljek (2005) noted that the increased level of foreign capital into the real estate market would raise the demand for property and consequently this would tend to drive real estate prices up in Croatia (due to the relatively fixed short-run supply of real estate).

Inconsistent with the above studies, Chan (2007) showed that FREI in China was not a cause of high house prices in recent years because FREI is a tiny portion of the total real estate investment in China. By using China's panel data of 35 main cities stretching from 1998 to 2007, Yu (2010) found that there is no relationship between FDI (as one of the economic fundamentals) and house prices. $\mathrm{Yu}$ (2010) also showed that house price in China is largely affected by government land policy. Similarly, in their study on the United Kingdom (UK) private commercial real estate market, Ling et al. (2009) found that capital flows are not a prime determinant of price movements.

\section{VARIABLE SELECTION}

In this section we set out the variables that we will consider for our empirical analysis. This choice will be guided by two considerations: from a theoretical and empirical perspective and the availability of data.

The purpose of this study is to examine the effect of FREI on house prices. Given the aim of our empirical analysis, an obvious variable to include is FREI. In order to identify FREI effects in the empirical model, we control for 
the variables that may affect house prices. In doing so, we include relevant variables that show relatively persistent results with respect to their influences on real estate price such as economic activities, long-term interest rate and construction costs. Our choice of control variables for the estimation process is based on the model of DiPasquale and Wheaton (1996).

It is expected that an increase in economic activities through, e.g., an increase in employment (resulting hike in households' labor income) or real industrial production increases the demand for houses. Since the real estate stock cannot change in the short-run, rents increase leading to higher house prices (Adams and Füss, 2010). Moreover, a higher labor income increases the possibility to get loans in the mortgage market. Therefore, housing demand increases which translates into higher house prices (Demary, 2010). Gross Domestic Product (GDP) is used as a proxy for economic activities.

A negative relationship between long-term interest rate and real estate price is expected. A higher long-term interest rate can reduce real estate prices in two ways (Adams and Füss, 2010). First, a higher long-term interest rate increases the return of other fixed-income assets (such as bonds) relative to the return of real estate, thus, shifting the demand from real estate into other assets leading to lower real estate prices. Second, a higher long-term interest rate is reflected in higher mortgage rates, which reduces demand and decreases real estate prices (Adams and Füss, 2010; Demary, 2010). For example, in their study on determinants of house prices in Central and Eastern Europe, Égert and Mihaljek (2007) found that real interest rate has a negative impact on house prices.

Finally, it is expected that higher construction costs (such as construction materials or labor costs) increase the house prices. It is because the higher construction costs lead to a decrease in construction and thus to a lower level of the housing stock. The lower housing stock means less housing space which raises rents. Higher rents then generate higher house prices in the asset market (Adams and Füss, 2010). The positive relationship between construction costs and house prices have been confirmed by several previous studies. For example, Adams and Füss (2010) found that a $1 \%$ increase in construction costs increase house prices by $1.3 \%$ in OECD countries from 1975 to 2007. Similarly, Hort (1998) showed that construction costs have a significant impact on real house prices in Swedish housing market. Wage per hour serves as a proxy for construction costs in the analyses.

Based on the above discussion, the following variables are chosen for our econometric investigation: house prices, FREI, economic activities (GDP or output), long-term interest rate and construction costs.

\section{METHODOLOGY AND DATA}

This paper seeks to examine the effects of an increase in the FREI on house prices in 21 emerging economies ${ }^{2}$ using annually data for the period 2000-2008. Included countries are all emerging economies for which data on all variables are obtainable.

Rather than analyzing the behavior in individual countries, we follow Kim and Yang (2011) who used panel Vector Autoregressive (VAR) techniques to better understand the dynamic relationships between capital inflows and asset prices. This technique combines the traditional VAR approach, which treats all the variables in the system as endogenous, with the panel-data approach, which allows for unobserved individual heterogeneity (Love and Zicchino, 2006). Moreover, VAR methodology fits the purpose of our study, given the absence of an a priori theory regarding the relationship

\footnotetext{
2 The country sample can be found in Appendix B.
} 
between the variables of our model. This is consistent with Guo and Huang (2010) who argued that VAR approach enables researchers to estimate the reaction of housing market to hot money shock without relying on a particular theory.

The VAR technique is a widely used approach for analyzing the relationship between capital inflows and asset prices (e.g., Guo and Huang, 2010; Jansen, 2003; Kim and Yang, 2009; Kim and Yang, 2011). Therefore, the VAR approach is suitable for our research question as well.

In our study, the VAR models the joint dynamics of the house prices, FREI, output and the long-term interest rate and construction cost as a linear dynamic system of equations. We select the lag order $k$ of the VAR system following the Akaike Information Criterion (AIC). It suggests applying a VAR with two lags.

VAR analysis involves the estimation of impulse response functions and variance decompositions. The impulse response function describes the reaction of one variable to the innovations in another variable in the system, while holding all other shocks equal to zero (Love and Zicchino, 2006). Variance decomposition analysis yield evidence for the percentage contribution of the different shocks to the variation in house prices.

Information on long-term interest rate, GDP and wage per hour has been obtained from Global Market Information Databases (GMID, 2010). Information on FREI has been obtained from various sources such as Thomson Reuters Datastream, OECD Statistics (2010) and Central Banks. The complete FREI data sources can be found in Appendix B. The relatively small size of our sample is due to the limited availability of the FREI series. We use housing price index as a proxy for house prices. Data on housing price index also comes from GMID (2010). It should be noted that we correct for country size by dividing FREI by population. The logarithm for $\mathrm{HP}$ and other variables is used.

\section{EMPIRICAL RESULTS}

This section contains the empirical results. First, we present the implications of the impulse response analysis. Given the purpose of this study, we are mostly interested in the effects of FREI shocks on house prices. Then we present variance decompositions analyses.

\section{Impulse responses to a FREI shock}

Table 1 contains estimated impulse responses to a shock to the FREI together with asymptotic standard errors. The FREI shock leads to an increase in the house prices in the emerging economies. In particular, we identify a positive effect of the FREI shock on house prices in emerging economies where it raises house prices by $0.36 \%$ after two years. This result is consistent with Mihaljek (2005) and Rodríguez and Bustillo (2010) who argue that the FREI could increase house prices in recipient countries. However, this outcome is not in line with the results reported by Chan (2007) who argued that FREI is not a cause of high house prices because FREI is a tiny portion of the total real estate investment. Moreover, we find that the FREI shock leads to an increase in the GDP after 2 years. However, the FREI shock leads to a decrease in interest rate and construction costs after 2 years.

Table 1. Responses to a FREI shock

\begin{tabular}{lll}
\hline Years after shock & 1 & 2 \\
\hline House prices & 0.278 & 0.361 \\
& $(0.153)$ & $(0.215)$ \\
GDP & 0.085 & 0.173 \\
& $(0.110)$ & $(0.574)$ \\
Interest rate & 0.027 & -0.341 \\
& $(0.157)$ & $(0.233)$ \\
Construction costs & -0.0289 & -0.073 \\
& $(0.029)$ & $(0.063)$ \\
\hline
\end{tabular}

Notes: Impulse responses to a shock to the FREI. Standard errors are given in parenthesis. 


\section{Impulse responses to an output (GDP) shock}

Table 2 contains impulse responses to an output shock. The output shock leads to an increase in the house prices in emerging economies. This result is consistent with Adams and Füss (2010) and Demary (2010) who argue that rising economic activities increases the demand for houses which can translate into higher house prices. Moreover, the results indicate that an increase in economic activity (GDP) leads to an increase in FREI, interest rate and construction costs.

Table 2. Responses to an output (GDP) shock

\begin{tabular}{lll}
\hline Years after shock & 1 & 2 \\
\hline House prices & $\begin{array}{l}0.663 \\
(0.567)\end{array}$ & $\begin{array}{l}0.678 \\
(0.360)\end{array}$ \\
FREI & $\begin{array}{l}0.036 \\
(0.045)\end{array}$ & $\begin{array}{l}0.023 \\
(0.045)\end{array}$ \\
Interest rate & $\begin{array}{l}0.061 \\
(0.157)\end{array}$ & $\begin{array}{l}0.211 \\
(0.192)\end{array}$ \\
Construction costs & 0.267 & 0.448 \\
& $(0.033)$ & $(0.061)$ \\
\hline
\end{tabular}

Notes: Impulse responses to a shock to an output. Standard errors are given in parenthesis.

\section{Impulse responses to an interest rate shock}

Interest rate shock has a negative impact onto the FREI and output (Table 3). On the other hand, interest rate shock has a positive impact on construction cost and house prices. In particular, we do not figure out any significant impact of interest rates on house prices $(0.02 \%)$ in emerging economies. This is not consistent with the findings of the previous studies in developed countries such as Adams and Füss (2010) and Demary (2010) who found that interest rate has a significant and negative impact on house prices.
Table 3. Responses to an interest rate shock

\begin{tabular}{lll}
\hline Years after shock & 1 & 2 \\
\hline House prices & 0.082 & 0.028 \\
& $(0.24)$ & $(0.320)$ \\
FREI & -0.652 & -0.439 \\
& $(0.641)$ & $(0.926)$ \\
GDP & -0.322 & -0.347 \\
& $(0.154)$ & $(0.167)$ \\
Construction costs & 0.025 & 0.016 \\
& $(0.029)$ & $(0.054)$ \\
\hline
\end{tabular}

Notes: Impulse responses to a shock to an interest rate. Standard errors are given in parenthesis.

\section{Impulse responses to a construction cost shock}

Table 4 contains impulse responses to a construction cost shock. The construction cost shock leads to an increase in the house prices (0.49\%) in emerging economies, as expected. The explanation of this finding is straightforward. The higher construction costs lead to a decrease in construction and thus to a lower level of the housing stock. The lower housing stock means less housing space which raises rents. Higher rents then generate higher house prices in the asset market. This result is in line with Hort (1998) and Adams and Füss (2010). Furthermore, the results of Table 4 indicate that the construction cost shock has positive impact on GDP and interest rate after two years.

Table 4. Responses to a construction cost shock

\begin{tabular}{lll}
\hline Years after shock & 1 & 2 \\
\hline House prices & 0.141 & 0.495 \\
& $(0.074)$ & $(0.189)$ \\
FREI & -0.073 & -0.032 \\
& $(0.082)$ & $(0.056)$ \\
GDP & 0.068 & -0.416 \\
& $(0.31)$ & $(0.291)$ \\
Interest rate & 0.036 & 0.040 \\
& $(0.050)$ & $(0.198)$ \\
\hline
\end{tabular}

Notes: Impulse responses to a shock to a construction cost. Standard errors are given in parenthesis. 


\section{Impulse responses to a house price shock}

House price shocks have a positive impact onto output, interest rates and construction costs (see Table 5). Moreover, we find a significant negative effect of house price shocks onto the FREI in emerging economies where they decrease FREI by 0.06 after two years. It is because when the house prices increase the demand for properties in emerging economies would decrease.

Table 5. Responses to a house price shock

\begin{tabular}{lll}
\hline Years after shock & 1 & 2 \\
\hline FREI & -0.091 & -0.061 \\
& $(0.045)$ & $(0.036)$ \\
GDP & -0.116 & 0.132 \\
& $(0.239)$ & $(0.366)$ \\
Interest rate & 0.514 & 0.178 \\
& $(0.160)$ & $(0.168)$ \\
Construction cost & 0.084 & 0.029 \\
& $(0.037)$ & $(0.063)$ \\
\hline
\end{tabular}

Notes: Impulse responses to a shock to a house price. Standard errors are given in parenthesis.

\section{Variance decompositions}

Table 6 shows variance decompositions of house prices with respect to the five shocks of the VAR. All reported numbers indicate the contribution of the shocks two years after they hit the economy. As can be seen from Table 6, most of the variation in house prices in emerging economies cannot be explained by shocks to FREI, output, interest rates and construction costs. In other words, fluctuation in housing market is the main source of house price swings in these countries over the period of study (84.5\%). Our results are in line with Zhu (2003) who provided evidences that most of the variation in housing prices can be explained by innovations in the housing market itself. Similarly, our result is consistent with Demary (2010) who found that the dominant source of house price fluctuations in developed countries comes from the housing market itself.

The FREI only explains $2.4 \%$ of the variation in house prices. Output shocks explain around $8.2 \%$ of the house price variation. Moreover, $1.2 \%$ of the variation in house prices can be traced back to the interest rate shock. Finally, construction cost shocks explain around $3.7 \%$ of the house price variation.

Summing up, our empirical results suggest that FREI contributes to house price increases. However, the dominant source of house price fluctuations in emerging economies comes from the housing market itself.

\section{CONCLUSION}

The aim of this paper has been to investigate the effect of foreign investment in real estate sector (FREI) on house prices in emerging economies over 2000-2008. In order to address this question empirically, we employed a panel VAR approach. The results of our analysis indicate that FREI is a significant determinant of house price appreciations. However, FREI only plays minor role in house price appreciations in the countries under study.

Since FREI has not contributed that much to house price appreciations in emerging economies, therefore, policymakers need not to be worry about the negative effects of FREI on real estate prices. In fact, governments

Table 6. Variance decomposition

\begin{tabular}{|c|c|c|c|c|c|}
\hline & $\begin{array}{l}\text { House price } \\
\text { shock }\end{array}$ & FREI shock & Output shock & $\begin{array}{l}\text { Interest rate } \\
\text { shock }\end{array}$ & $\begin{array}{l}\text { Construction } \\
\text { cost shock }\end{array}$ \\
\hline \multicolumn{6}{|c|}{ Percentage contribution of ... to house price fluctuations } \\
\hline Emerging economies & 84.5 & 2.4 & 8.2 & 1.2 & 3.7 \\
\hline
\end{tabular}


in these countries should attempt to attract more foreign investors into their real estate sectors because FREI has several benefits for host economies such as injection of financial resources, generating employment, facilitating urban development, introducing additional competition in real estate sector, introducing new practices in the operation of real estate industry, attracting international tourists and leaving a favorable impact on the enrollment in higher education ${ }^{3}$. However, policymakers should prevent speculative capital flow into the real estate sector that can drive up real estate prices and make property bubbles.

Ultimately, the results of the study should be considered in light of its limitations, which also point to some issues for future research. First, the present study only considered the aggregate FREI for analysis. For future research, it may be useful to examine the relationship between FREI and real estate prices by using disaggregate data for various types of real estate such as residential and commercial real estate. Secondly, the number of 21 emerging economies in our sample is one of the study's limitations. Given the data constraints, results should be viewed with caution and hence data from more countries is needed to fully investigate this relationship and improve our understanding.

\section{REFERENCES}

Adams, Z. and Füss, R. (2010) Macroeconomic determinants of international housing market, Journal of Housing Economics, 19(1), pp. 3850. http://dx.doi.org/10.1016/j.jhe.2009.10.005

Basu, B. and Yao, J. (2009) Foreign direct investment and skill formation in China, International Economic Journal, 23(2), pp. 163-179. http://dx.doi.org/10.1080/10168730902901106

3 See Rodriguez and Bustillo (2010), Basu and Yao (2009), Wei et al. (2006), Wu (2001), He et al. (2009) and Jiang et al. (1998).
Ben-Yehoshua, A. (2008) Foreign direct investment in the Chinese real estate industry. [Online] The Israeli Chamber of Commerce in Shanghai. Available at: http://www.ischamshanghai. org [accessed 26 May 2011]

Bo, S. and Bo, G. (2007) Impact of international capital flows on real estate market: The empirical test in China from 1998 to 2006, Frontiers of Economics in China, 2(4), pp. 520-531. http:// dx.doi.org/10.1007/s11459-007-0027-8

Brixiova, Z., Vartia, L. and Worgotter, A. (2010) Capital flows and the boom-bust cycle: The case of Estonia, Economic Systems, 34(1), pp. 55-72. http://dx.doi.org/10.1016/j.ecosys.2009.11.002

Calvo, G. A., Leiderman, L. and Reinhart, C. M. (1996) Inflows of capital to developing countries in the 1990s, The Journal of Economic Perspectives, 10(2) pp. 123-139. http://dx.doi.org/10.1257/jep.10.2.123

Chan, N. (2007) Should foreign real estate investment be controlled in China?, Pacific Rim Property Research Journal, 13(4), pp. 473-492.

Chari, V. V. and Kehoe, P. (2003) Hot money, Journal of Political Economy, 111(6), pp. 12621292. http://dx.doi.org/10.1086/378528

Cheng, L. W., Zhang, T. T. and Sun, W. (2006) The empirical study of the impact of FDI in real estate on price of real estate. In: International conference on construction \& real estate management, 1 and 2, pp. 1547-1549.

Copeland, B. (1991) Tourism, welfare, and de-industrialization in a small open economy, Economica, 58(232), pp. 515-529. http://dx.doi. org/10.2307/2554696

Cordero, J. and Paus, E. (2008) Foreign investment and economic development in Costa Rica: the unrealized potential, Working Group on Development and Environment in the Americas. Discussion paper, No. 13, pp. 1-27.

Demary, M. (2010) The interplay between output, inflation, interest rates and house prices: international evidence, Journal of Property Research, 27 (1), pp. 1-17. http://dx.doi.org/10.10 80/09599916.2010.499015

DiPasquale, D. and Wheaton, W. C. (1996) Urban economics and real estate markets. New Jersey: Prentice-Hall.

Downs, A. (2007) Credit crisis: The sky is not falling. [Online] The Brookings Institution. Available at: http://www.brookings.edu/papers/2007/10_ mortgage_industry_downs.aspx 
Economist Intelligence Unit (2008) Hot property, Business India Intelligence, April 16th 2008.

Égert, B. and Mihaljek, D. (2007) Determinants of house prices in Central and Eastern Europe, BIS Working Papers, (236), pp. 2-26.

GMID (2010) Global Market Information Databases. [Online] Available at: http://www.portal. euromonitor.com/Portal/Magazines/Welcome. aspx [accessed 20 May 2011]

Guerra de Luna, A. (1997) Residential real estate booms, financial deregulation and capital inflows: An international perspective, Mimeo, Banco de Mexico.

Guo, F. and Huang, Y. S. (2010) Does "hot money" drive China's real estate and stock markets?, International Review of Economics \& Finance, 19(3), pp. 452-466. http://dx.doi.org/10.1016/j. iref.2009.10.014

He, C., Wang, J. and Cheng, S. (2009) What attracts foreign direct investment in China's real estate development?, The Annals of Regional Science, 46(2), pp. 267-293. http://dx.doi.org/10.1007/ s00168-009-0341-4

Hort, K. (1998) The determinants of urban house price fluctuations in Sweden 1968-1994, Journal of Housing Economics, 7(2), pp. 93-120. http://dx.doi.org/10.1006/jhec.1998.0225

Jansen, W. J. (2003) What do capital inflows do? Dissecting the transmission mechanism for Thailand, 1980-1996, Journal of Macroeconomics, 25(4), pp. 457-480. http://dx.doi.org/10.1016/j. jmacro.2002.06.003

Jiang, D., Chen, J. J. and Isaac, D. (1998) The effect of foreign investment on the real estate industry in China, Urban Studies, 35(11), pp. 21012110. http://dx.doi.org/10.1080/0042098984024

Ling, D. C. and Marcato, G. and McAllister, P. (2009) Dynamics of asset prices and transaction activity in illiquid markets: The case of private commercial real estate, Journal of Real Estate Finance and Economics, 39(3), pp. 359-383. http://dx.doi.org/10.1007/s11146-0099182-2

Love, I. and Zicchino, L. (2006) Financial development and dynamic investment behavior: Evidence from panel VAR, The Quarterly Review of Economics and Finance, 46(2), pp. 190-210. http://dx.doi.org/10.1016/j.qref.2005.11.007

Kim, S. and Yang, D. Y. (2009) Do capital inflows matter to asset prices? The case of Korea, Asian
Economic Journal, 23(3), pp. 323-348. http:// dx.doi.org/10.1111/j.1467-8381.2009.02014.x

Kim, S. and Yang, D. Y. (2011) The impact of capital inflows on asset prices in emerging Asian economies: Is too much money chasing too little good?, Open Economy Review, 22(2), pp. 293315.

http://dx.doi.org/10.1007/s11079-009-9124-x

Mihaljek, D. (2005) Free movement of capital, the real estate market and tourism: A blessing or a curse for Croatia on its way to the European Union? In: Ott, K. (ed.), Croatian Accession to the European Union: Facing the Challenges of Negotiations, Institute of Public Finance, 3, pp. 185-228.

OECD Statistics (2010) OECD Stat Extract. [Online] Available at: http://stats.oecd.org/Index. aspx [accessed 23 May 2011]

Rajan, R. S. and Siregar, R. (2002) Private capital flows in East Asia: Boom, bust and beyond. In: de Brouwer, G. (ed.), Financial Markets and Policies in East Asia, Policies in East Asia, Routledge Press, pp. 47-81. http://dx.doi. org/10.4324/9780203398340_chapter_4

Rangel, G. J. (2010) Evidence, determinants, and consequences of asset price bubbles: The case of Malaysia and Singapore, Unpublished PhD Dissertation, School of Management, Universiti Sains Malaysia (USM).

Redman, A. L. and Gullett, N. S. (1998) An empirical study of the impact of foreign ownership on the values of U.S. commercial properties, Journal of Financial and Strategic Decisions, 11(1), pp. 53-60.

Rodríguez, C. and Bustillo, R. (2010) Modeling foreign real estate investment: The Spanish case, Journal of Real Estate Finance and Economics, 41(3), pp. 354-367. http://dx.doi.org/10.1007/ s11146-008-9164-9

Sajor, E. E. (2003) Globalization and the urban property boom in Metro Cebu, Philippines, Development and Change, 34(4), pp. 713-741. http://dx.doi.org/10.1111/1467-7660.00325

Wei, Y. D., Leung, C. K. and Luo, J. (2006) Globalizing Shanghai: Foreign investment and urban restructuring, Habitat International, 30(2), pp. 231-244. http://dx.doi.org/10.1016/j.habitatint.2004.02.003

World Bank (2001) Global development finance: Country tables and global development finance, 
building coalitions for effective development finance. World Bank, Washington DC.

Wu, F. (2001) China's recent urban development in the process of land and housing marketisation and economic globalization, Habitat International, 25 (3), pp. 273-289. http://dx.doi. org/10.1016/S0197-3975(00)00034-5

Yu, H. (2010) China's house price: Affected by economic fundamentals or real estate policy?, Frontiers of Economics in China, 5(1), pp. 2551. http://dx.doi.org/10.1007/s11459-010-0002-7
Zheng, S., Kahn, M. E. and Liu, H. (2009) Towards a system of open cities in China: Home prices, FDI flows and air quality in 35 major cities, NBER Working Paper, No. 14751, February 2009, pp.1-33.

Zhu, H. (2003) The importance of property markets for monetary policy and financial stability, Bank for International Settlements Papers No 21, pp. 9-29.

APPENDIX A. FDI Inflows into real estate sector (millions of US dollars)

\begin{tabular}{|c|c|c|c|c|}
\hline \multirow[t]{2}{*}{ Country } & \multicolumn{2}{|l|}{2004} & \multicolumn{2}{|l|}{2007} \\
\hline & FREI & $\begin{array}{l}\text { GDP from real } \\
\text { estate, renting and } \\
\text { business activities } \\
\text { (GDPR) }\end{array}$ & FREI & $\begin{array}{l}\text { GDP from real } \\
\text { estate, renting and } \\
\text { business activities } \\
\text { (GDPR) }\end{array}$ \\
\hline Bulgaria & 326 & 3,406 & na & 5,586 \\
\hline China & 5,950 & 171,285 & 17,088 & 338,602 \\
\hline Croatia & 0 & 5,394 & 74 & 9,482 \\
\hline Czech & 656 & na & 1,680 & na \\
\hline Estonia & 11 & na & 80 & na \\
\hline Hungary & 285 & 14,613 & 649 & 21,118 \\
\hline Israel & 795 & na & 1,564 & na \\
\hline Kazakhstan & 7 & 6,495 & 70 & 14,715 \\
\hline Latvia & -37 & 1,703 & 411 & 4,086 \\
\hline Lithuania & 57 & 2,147 & 168 & 4,592 \\
\hline Malaysia & 159 & 4,779 & 398 & 8,172 \\
\hline Mexico & 8 & 124,107 & 16 & 159,971 \\
\hline Philippine & 0.3 & 8,234 & 10 & 14,131 \\
\hline Poland & 844 & 30,116 & 2,363 & 51,173 \\
\hline Romania & 1,229 & 7,609 & 4,827 & 20,130 \\
\hline Serbia & 54 & 3,135 & 388 & 5,811 \\
\hline Slovakia & 157 & na & 600 & na \\
\hline South Korea & -224 & na & 729 & na \\
\hline Thailand & -38 & 4,680 & 115 & 6,226 \\
\hline Tunisia & 30 & 3,676 & 100 & 4,655 \\
\hline Turkey & 40 & 46,961 & 449 & 96,450 \\
\hline
\end{tabular}




\section{APPENDIX B. Country sample and FREI data sources}

\begin{tabular}{ll}
\hline Countries & Source \\
\hline Czech, Estonia, Hungary, Mexico, Poland, Slovakia, South Korea, Turkey & OECD Statistics \\
China & $\begin{array}{l}\text { National Bureau } \\
\text { of Statistics of China }\end{array}$ \\
Israel & Ministry of Finance \\
Bulgaria, Kazakhstan, Philippine, Romania, Thailand & Thomson Reuters Datastream \\
Latvia & Central Bank \\
Lithuania & Central Bank \\
Croatia & Central Bank \\
Malaysia & Ministry of Finance \\
Tunisia & Central Bank \\
Serbia & National Bank of Serbia \\
\hline
\end{tabular}

